\title{
Transfer Pricing and Controlled Transactions in Connection with Earnings Management and Tax Avoidance
}

\author{
Katarina Kramarova ${ }^{1, *}$ \\ ${ }^{1}$ University of Zilina in Zilina, Faculty of Operation and Economics of Transport and \\ Communications, Department of Economics, Univerzitna 8215/1, 01026 Zilina, Slovakia
}

\begin{abstract}
.
Research background: The way of pricing intra-group transactions (controlled transactions in the terms of transfer pricing) should be in line with the arm's length principle, whether we consider nationally or transnationally related business entities. If this is not the case, these operations are a tool for earnings management between the companies. It is known that income tax is perceived by businesses as an unproductive withdrawal of own funds without obvious consideration, and therefore managing economic transactions at the level of related-party entities in order to minimize the tax liability is obvious and even expected.

Purpose of the article: The aim of the paper is to find out if controlled transactions are used in connection with earnings management and tax avoidance in the selected Slovak company using proxies, which may carry this detection capability (ratios of related party transactions, book-tax differences ratio, and discretionary accruals ratio).

Methods: The analytical part of the paper follows the Slovak transfer pricing legislation in force. Following the existing research studies, we test hypothetical relationship between the indicators of earnings management, related party transactions and tax avoidance by applying correlation analysis. We worked mainly with publicly available data from financial statements and notes to financial statements.

Findings \& Value added: The results indicate that the company managed earnings rather downwards, since the values of discretionary accruals ratio were negative. On the other side, it was not proven that earnings management was carried out purely with the intention of minimizing tax liability.
\end{abstract}

Keywords: controlled transactions; earnings management; tax avoidance; transfer pricing

JEL Classification: $H 26 ; K 34 ; M 41$

*Corresponding author: katarina.kramarova@,fpedas.uniza.sk 


\section{Introduction}

According to the OECD, the term "tax" is confined to compulsory, unrequited payments to general government. Generally, taxes are unrequited in the sense that benefits provided by government to a taxpayer are not normally in proportion to a taxpayer's payments. [1] One of the main missions of taxes is therefore to ensure the flow of revenues to the state budget, and thus to ensure monetary relations associated with the performance of functions of the state; in this context primarily income taxes and value added tax are discussed. It is therefore a logical goal of every state to streamline tax collection, tax legislation, and minimize tax avoidance and tax evasion.

In this context, transfer pricing is one of the most discussed tax areas. Transfer price is the price contained in each product or service including the use of a property of a tangible or an intangible nature from one division to another in the same company or between companies that have a special relationship. [2] Related-party transactions may be motivated by objective factors, e.g. business strategy of the business group as a whole, improvement of the group's position on the market, economic conditions of the market where the transaction takes place, etc. In some cases, however, such transactions are motivated by an effort to minimize the tax liability of a group of related entities as a whole. From a tax perspective, prices of intragroup transactions are a mean for allocating the profits between the various legal entities involved in related-party transactions of an economic nature. [3, 4] Methodology for assessing the correctness of intragroup transactions is based on the assessment of compliance with the arm's length principle, which in most countries is codified directly in the business and tax legislation. Transfer pricing that meets the arm's length principle eliminates distortions in related-party transactions. Until recently, transfer pricing was perceived more as an issue of multinational companies and international taxation. At present, it is already being addressed at the national level, in close connection with economic activities of resident related parties. At the same time, it is being discussed how important role it plays in managing earnings in case of related business entities by accepting the existence of the legal frame governing this issue.

\section{Literature review}

The general definition of earnings management defines it as a series of decisions taken by responsible managers in the field of accounting and reporting of economic transactions to signal financial information to external users to assist them to improve their understanding of company's current or upcoming performance. [5] In practice, earnings management is rather negative since activities of managers are of an opportunistic nature they mostly act for other than enhancing truthful reporting (i.e. it is financial reporting aggressiveness), e.g. to fulfil bonus incentives, debt contracts, political costs (including tax burden) etc. $[4,6,7]$ Earnings management disposes with a range of tools applicable to stakeholders' interests, including tax management. Within it, earnings management may operate with related-party transactions. Transfer pricing manipulates the amount of accounting profit, thereby affecting the tax to be received by the government, dividends that will be received by shareholders and managerial bonuses for economic results. Scott proves that opportunistic policies of management to manage earnings are motivated by the amount of tax that is borne by the company as a tax-payer, so that the tax burden owed becomes smaller due the fact that the accounting profit has been managed by the management. [8] 
Efforts to maintain earnings even increase them can be done through reducing the tax burden that must be borne by the company by utilizing existing legislation or beyond applicable accounting and tax principles. [8-11] Kramarova - Valaskova state that in the case of Slovakia, the main reason of earnings management and financial reporting aggressiveness is tax avoidance (regardless of the detailed specification of the type of tax), while establishing it as a legal or illegal activity depends on the degree of legal regulation in this area. [11] In connection with the transfer pricing, e.g. Rasheed et al. state that the extant of involvement of related entities in transfer pricing affects the extent of the company's financial reporting aggressiveness. [12] Beuselinck - Deloof confirm that the extent of fraudulent financial reporting was larger in case of business groups than in case of non-business groups. [13] Given findings are confirmed also by [4]. He states that relatedparty entities avoided tax by using related-party transaction and transfer pricing. In the same study he also found out, that the extant of tax avoidance decreased after the implementation of the Unfair Related Party Transaction Tax Law. According to Slovakia, Danovsky - Krammer state that the tax offices (whose activities fall within the scope of the Financial Administration of the Slovak Republic) consider business entities that report losses to be particularly risky. A situation where one company in a group reports loss while the rest of the companies in the group make a profit may trigger tax control in relation to transfer pricing. The tax controls focus primarily on individual industry sectors, with the decisive factor in the selection being the profitability and size of the sector. Subsequently, transactions relating to services, production and sales of products, royalties, financial transactions and corporate restructuring are examined in particular. [14]

\section{Methodology}

The aim of the study is to analyse the use of transfer pricing in earnings management by chosen indicators and relevant earnings management detection technique in conditions of the selected Slovak business entity by accepting the potential relationship between transfer pricing, tax avoidance/evasion and earnings management. The indicators were selected so that they could be quantified from the available financial statements of the company, including notes to the financial statements. Following the research e.g. by $[4,10,15,16]$ etc. the amount of related-party transactions (RPT) we calculated as the ratio of their monetary value and the value of all transactions of a given type. We took into account all economic transactions with the direct impact on the economic results of the company. From the accounting point of view, these are transactions of a revenue and cost nature. Although such economic transactions are a common feature of business, they may give rise to specific risks of material misstatement of the financial statements, including the risk of tax fraud, because of the nature of related party relationships.

Tax avoidance will be seen in accordance with the definition of [9], i.e. as downward manipulation of taxable income through tax planning that may or may not be considered fraudulent tax evasion. To measure tax avoidance, we used book-tax differences ratio (BTDs). We based on the same assumption as e.g. [9, 17, 18] that BTDs are indeed indicative of opportunistic reporting behaviour, and even more so of earnings management. Tang states that BTDs are a useful indicator of earnings and tax management after accounting for the mechanical differences due to the divergent reporting rules for book and tax purposes. [19] According to [20], large BTDs are a sign of growth of discretionary accruals, so companies should show less persistent earnings and accruals. There is a substantial diversity with respect to the measurement of BTDs as well as with regard to the definition of the proxies. [17] For the needs of our study, we decided to use the total BTDs (TBTDs) as suggested [21]. TBTDs represent the most comprehensive measure and capture both temporary and permanent BTDs. [17] 
TBTDs is the difference between the net income $(\mathrm{NI}=\mathrm{EAT})$ in time $\mathrm{t}$ and the taxable income (TI) in time $t$ divided by the average total assets (TA). TI is the result of dividing the current income tax expenses of the period (T) by the corporate income tax rate (ITR) because the information on TI is not available in the financial statements (it is a part of tax return, which is not publicity available). I.e. in the case of the analysed company, TI is the estimation of the tax base for the calculation of corporate income tax. TI is then multiplied by ( 1 - ITR) to make it comparable to net income, which is measured after tax. [21]

Financial aggressiveness as the action of earnings management we calculated through discretionary accruals as suggested by $[10,22]$. We used following formula:

$$
D A_{t}=T A_{t}-N D A_{t}=\left(N I_{t}-C F \text { operation }_{t}\right) / A_{t-1}-\left(1 / A_{t-1}+\Delta R E V / A_{t-1}-\Delta R E C / A_{t-1}+P P E_{t} / A_{t-}\right.
$$

where:

$\mathrm{DA}_{\mathrm{t}}-$ discretionary accruals

$\mathrm{TA}_{\mathrm{t}}-$ total accruals

$\mathrm{NDA}_{t}-$ non-discretionary accruals

$\mathrm{NI}_{t}-$ net income (EAT)

$\mathrm{A}_{\mathrm{t}-1}$ - total assets in the year previous to analysis

$\triangle \mathrm{REV}$ - year-on-year change in revenues

$\triangle \mathrm{REC}$ - year-on-year change in account receivable

$\mathrm{PPE}_{\mathrm{t}}$ - fixed assets

$\mathrm{ROA}_{t}$ - return on assets

\section{Results}

The legal framework of individual countries is created under the influence of various endogenous and exogenous factors. [23] They determine the uniqueness of tax systems, which, on the one hand, are linked to the need to harmonize legal systems at the level of supranational entities and, on the other hand, to reflect specificities of national environments.

The basic and transnationally accepted principle of transfer pricing - arm's length principle - in case of Slovakia is enacted in the Section 18 (1) of the Act No. 595/2003 Coll. on Income Tax Act as amended (as "ITA"). Given Act together with the Guidelines of the Ministry of Finance of the Slovak Republic MF/019153/2018-724 on Details Regarding the Content for Keeping Documentation for Transfer Pricing Method and Methodological Guideline on the Transfer Pricing Methods of the Financial Directorate of the Slovak Republic are the primary legislation governing the issue of transfer pricing in Slovakia.

The analysis of the legislation frame shows that transfer pricing only applies to controlled transactions, which are a legal relationship or other similar relationship between two or more related parties, where at least one of the parties is a taxpayer with the income from entrepreneurship, other self-employment, lease or from using of work and artistic performance (pursuant to the Section 6 of the ITA) or a legal entity (a company) that achieves taxable income from entrepreneurship or from disposal with the property (Section $2 \mathrm{ab}$ ) of the ITA). The term "related party" means a close person (following the Sections 116 and 117 of the Act No. 40/164 Coll. on Civil Code as amended), or a person with economic, personal or other ties (commercial relationship established particularly for the purposes of tax base decrease or tax loss increase), or a person or entity that is part of a consolidated group for consolidation purposes (following the Section 22 of the Act No. 431/ 2001 Coll. on Accounting Act as amended). The term non-resident related party (foreign related party) is a situation, in which a resident individual or legal entity has ties to 
a non-resident individual or a non-resident legal entity. The above shall apply also to the relation between a taxpayer with unlimited tax liability and its permanent establishments abroad, and to the relationship between a taxpayer with limited tax liability and its permanent establishment in the territory of Slovakia and the relationship between permanent establishments of taxpayers with ties as set (following the Section $2 \mathrm{n}$ ) of the ITA) and to the relationship between these permanent establishments and these taxpayers.

As far as the analysed company is concerned, the company is identified for the purposes of transfer pricing only as a domestic dependent person. The connections with other persons and entities are of an economic and personnel nature (apparent involvement of the company in the assets, control and management of another company). All controlled transactions are of a significant nature, which means that the company is obliged to keep transfer documentation about all kinds of controlled transactions. The transactions have the character of purchased services, including rental of properties and received financial loans (other than bank loans). From an accounting point of view, these are the transactions of a cost nature, which reduce the company's earnings. The company does not carry out control transactions of a revenue nature except the year 2013. However, their monetary value in comparison with total revenues exceeding 19 mil. EUR did not reach even $0.01 \%$.

In terms of classification of economic activities, the company provides services of advertising agency (SK NACE 73.11).

By law, the company has being obliged to keep extra-simplified transfer documentation (abridged transfer pricing documentation) since January 2015. In addition, the company also provides information on the transactions in the notes to financial statements and in the annual reports. It follows from the facts stated by the company that the pricing policy of controlled transactions should be in line with the arm's length principle, as the company states in the documents that it applies the same prices in controlled as in uncontrolled transactions. Until 2015, it did not provide information on controlled transactions in the annual report and in the notes to financial statements. This information, which we worked with, has the character of internal one. The company accounts in accordance with the Slovak accounting standards. Its financial statements are audited.

The average value of income tax payable from 2010 to 2019 was EUR 267,299; the average value of net profit was EUR 869,822. The company was profitable in all analysed years, with the exception of 2019, when it reported an accounting loss of EUR 782,701. The average effective tax rate was $20.1 \%$, and thus $4.26 \%$ lower than the statutory average tax rate for individual years. CF from operating activities reached an average value of EUR $3,099,340$. The average ROAEAT was $5 \%$.

The value of the RPT ratio for all years is 0.02879 , i.e. controlled transactions of the cost nature accounted for $2.88 \%$ of all cost transactions. After the introduction of the obligation to keep transfer pricing documentation on domestic controlled transactions (since 2015), the average value of the indicator decreased to 0.02090 .

DA as a proxy in measuring financial statements aggressiveness indicates that the analysed company managed earnings rather downwards, since the values of DA were negative in all years; the exception is 2018. This may indicate the company's effort to minimize its tax duties. The average value of the DA ratio accounted for (-) 0.75330 . If we consider only the years after the introduction of the obligation to keep transfer pricing documentation on domestic controlled transactions, the average value of DA dropped to (-) 0.66250 .

TBTDs as a proxy in measuring tax avoidance shows fluctuations over the analysed years. Its average value accounted for (-) 0.00701. If we consider only the years after the introduction of the obligation to keep transfer pricing documentation on domestic controlled transactions, the value of TBTDs lower, namely (-) 0.01001 .

Selected financial indicators are summarized in the following table. 
Table 1. Selected financial indicators.

\begin{tabular}{|c|c|c|c|c|c|}
\hline $\begin{array}{c}\text { Indicator/ } \\
\text { Year }\end{array}$ & 2010 & 2011 & 2012 & 2013 & 2014 \\
\hline \multirow[t]{3}{*}{$\begin{array}{c}\text { Income tax } \\
\text { payable }\end{array}$} & 141,070 & 308,426 & 82,127 & 59,624 & 190,364 \\
\hline & 2015 & 2016 & 2017 & 2018 & 2019 \\
\hline & 483,997 & 704,574 & 397,058 & 305,663 & 87 \\
\hline \multirow[t]{4}{*}{$\begin{array}{c}\text { Net income } \\
\text { (EAT) }\end{array}$} & 2010 & 2011 & 2012 & 2013 & 2014 \\
\hline & 534,065 & $1,182,775$ & 382,586 & 166,665 & 552,646 \\
\hline & 2015 & 2016 & 2017 & 2018 & 2019 \\
\hline & $1,730,968$ & $2,503,266$ & $1,409,794$ & $1,018,244$ & $-782,788$ \\
\hline \multirow[t]{4}{*}{ Tax rate $(\%)$} & 2010 & 2011 & 2012 & 2013 & 2014 \\
\hline & 19 & 19 & 19 & 23 & 22 \\
\hline & 2015 & 2016 & 2017 & 2018 & 2019 \\
\hline & 22 & 22 & 21 & 21 & 21 \\
\hline \multirow[t]{4}{*}{$\begin{array}{l}\text { Taxable } \\
\text { income }\end{array}$} & 2010 & 2011 & 2012 & 2013 & 2014 \\
\hline & 601,404 & $1,314,869$ & 350,120 & 199,611 & 674,927 \\
\hline & 2015 & 2016 & 2017 & 2018 & 2019 \\
\hline & $1,715,989$ & $2,498,035$ & $1,493,694$ & $1,149,875$ & 327 \\
\hline \multirow[t]{4}{*}{ Assets } & 2010 & 2011 & 2012 & 2013 & 2014 \\
\hline & $17,107,277$ & $16,495,162$ & $16,413,074$ & $15,734,703$ & $15,327,879$ \\
\hline & 2015 & 2016 & 2017 & 2018 & 2019 \\
\hline & $17,036,366$ & $19,191,769$ & $19,472,660$ & $18,835,984$ & $19,616,725$ \\
\hline \multirow[t]{4}{*}{ TBTDs } & 2010 & 2011 & 2012 & 2013 & 2014 \\
\hline & -0.00394 & -0.00801 & 0.00198 & -0.00209 & -0.00798 \\
\hline & 2015 & 2016 & 2017 & 2018 & 2019 \\
\hline & 0.00088 & 0.00027 & -0.00431 & -0.00699 & -0.03992 \\
\hline \multirow[t]{4}{*}{ ROA eat } & 2010 & 2011 & 2012 & 2013 & 2014 \\
\hline & 0.03122 & 0.07170 & 0.02331 & 0.01059 & 0.03605 \\
\hline & 2015 & 2016 & 2017 & 2018 & 2019 \\
\hline & 0.10160 & 0.13043 & 0.07240 & 0.05406 & -0.03990 \\
\hline \multirow[t]{4}{*}{ DA } & 2010 & 2011 & 2012 & 2013 & 2014 \\
\hline & -0.79042 & -0.90363 & -0.81902 & -1.92514 & -1.88226 \\
\hline & 2015 & 2016 & 2017 & 2018 & 2019 \\
\hline & -1.04833 & -1.05318 & -0.53958 & 0.61523 & -1.28664 \\
\hline \multirow[t]{4}{*}{ RPT } & 2010 & 2011 & 2012 & 2013 & 2014 \\
\hline & 0.01978 & 0.02968 & 0.04759 & 0.04831 & 0.03797 \\
\hline & 2015 & 2016 & 2017 & 2018 & 2019 \\
\hline & 0.01633 & 0.02591 & 0.02655 & 0.01474 & 0.01800 \\
\hline
\end{tabular}

As we have mentioned, the company if managed earnings, it managed them downwards. According the analysis of hypothetical relationships between the proxies, the results indicate that between the DA ratio and the RPT indicator is an indirect relationship of moderate intensity (coefficient of correlation $r=(-) 0.55505)$. I.e. in the case of a decrease in the share of considered controlled transactions in the total volume of transactions of a given type, the value of the indicator indicating the degree of propensity to earnings management and aggressiveness financial reporting would increase (from negative values it would "shift" to zero). This means that the rate at which profits are reduced, it would decrease. In the case of an increase in the share of controlled transactions, the DA ratio would develop ad versa. From a statistical point of view, the linear dependence of the 
indicators is statistically significant that confirmed the test of linear independence at the significance level $\alpha=0.1$ ( $|\mathrm{T}|$ statistics $\left.=1,88736 ; \mathrm{t}_{0,9 ; 8}=1,85955\right)$.

From the analysis of the impact of earnings management on tax avoidance is obvious that earnings management could be implemented for the purpose of tax avoidance, however the linear dependence is low (coefficient of correlation $r=0.10785$ ) and statistically it was not confirmed as significant. Based on the results, we deduce that tax management was not the only reason why opportunistic earnings management occurred in the company. In analysing the potential relationship of controlled transactions and transfer pricing on tax avoidance, we have concluded that RPT had a positive effect on tax avoidance of a medium strength (coefficient of correlation $r=0.33895$ ). The result therefore suggests that in the case of a decrease in the share of controlled transactions in the total volume of transactions of a given type, the value of TBTDs would decrease. At the same time, the result suggests that controlled transactions were not the only proxies that contributed to a potential disproportion between accounting and tax profits.

\section{Discussion}

The results of the analysis indicate the potential relationship between the indicators, which point out ad 1) the importance of controlled transactions and transfer pricing in connection with earnings management, ad 2) the link between earnings management and tax avoidance, and ad 3) the potential relationship between controlled transactions and tax avoidance. The analysis shows that the analysed company managed earnings rather downwards, since the values of the DA indicator were negative, i.e. that the company reduced the earnings. In the case of a decrease in the share of controlled transactions in the total volume of transactions of a given type, the value of the DA ratio that is a measure of earnings management, the rate by which profits are reduced would decrease (the value of the coefficient would increase towards 0 ). Regarding the relationship between earnings management and tax avoidance, the positive effect was not statistically confirmed, as well as the relationship between controlled transactions and tax avoidance. On the other hand, it is not excluded that there is other than a linear relationship between the observed variables. We consider the analysis performed and the obtained results as an input analysis of potential relationships between the observed variables. To do analysis that is more comprehensive and to get results, which are more valuable it would be appropriate to implement mediation analysis that can contribute to better understanding the relationship between variables when these variables do not have an obvious direct connection.

This paper was supported by the Slovak Research and Development Agency under Grant number APVV-17-0546: Variant Comprehensive Model of Earnings Management in Conditions of the Slovak Republic as an Essential Instrument of Market Uncertainty Reduction.

\section{References}

1. OECD (1996). Definition of taxes. Retrieved from: https://www.oecd.org/daf/mai/pdf/eg2/eg2963e.pdf.

2. Santosa, S. J. D., Suzan, L. (2018). Pengaruh pajak, tunneling incentive, dan mekanisme bonus terhadap transfer pricing. Kajian Akuntansi, 19(2), 76-83.

3. Kramarova, K., Bartosova, V., Gajanova, L., Havelkova, A. (2019). Controlled transactions of legal entities of the public administration in the Slovak Republic and resulting consequences. Proceedings of Modernization of public administration: 
conference proceedings (pp. 81-86). Straznice: Public administration educational institute.

4. Park, S. (2018). Related party transactions and tax avoidance of business group. Sustainability, 10, 1-14.

5. Kaya, T., Turegun, N. (2017). Associations between earnings management manipulation types and debt contracts, political costs and characteristics of board of directors. International Journal of Academic Research in Accounting, Finance and Management Sciences, 7(2), 208-214.

6. Healy, P. M., Wahlen, J. M. (1999). A review of the earnings management literature and its implications for standard setting. Accounting Horizons, 13(4), 365-383.

7. Watts, L. R., Zimmerman, L. J. (1989). Positive accounting theory: A ten-year perspective. Accounting Revue, 65, 131-156.

8. Scott, W. R. (2015). Financial accounting theory, $7^{\text {th }}$ edition. Toronto: Pearson Canada.

9. Frank, M. M., Lynch, L. J., Rego, S. O. (2009). Tax reporting aggressiveness and its relation to aggressive financial reporting. Accounting Revue, 84, 467-496.

10. Hieranti, E., Chairina, S. W. (2019). Does transfer pricing improve the tax avoidance through financial reporting aggressiveness? Proceedings of International Conference on Economics, Management, and Accounting (pp. 357-376). KnE Social Science.

11. Kramarova, K., Valaskova, K. (2020). Application of chosen fraudulent detection technique in the Slovak business environment. Proceedings of Globalization and its socio-economic consequences: sustainability in the global-knowledge economy: 19th international scientific conference: conference proceedings (pp. 1-8), Rajecke Teplice, Slovak Republic.

12. Rasheed, P. C., Abdul, P. C., Mallikarjunappa, T. (2018). Related party transactions and earnings management: An empirical examination of selected companies in India. IUP Journal of Accounting Research and Audit Practices, 17, 22-35.

13. Bauselinck, Ch., Deloof, M. (2014). Earnings management in business groups: Tax incentives or expropriation Concealment? International Journal of Accounting, 49(1), 27-52.

14. Danovsky, P., Krammer, K. (May 2018). Pohl'ad daniarov na transferové oceňovanie sa sprísňuje. Target News. Retrieved from: http://targetnews.sk/clanky/item/601pohlad-daniarov-na-transferove-ocenovanie-s-a-sprisnuje

15. Lee, D. The effect of controlling company's tax burden on income shifting through intra-transaction. Korean Accounting Revue, 35, 147-182.

16. Gordon, E. A., Henry, E. (2005). Related party transactions and earnings management. Retrieved from: https://ssrn.com/abstract=612234.

17. Evers, M. T., Meier, I., Nicolay, K. (2016). The implications of book-tax differences: A meta-analysis. Discussion paper no. 17-003.

18. Wilson, R. J. (2009). An examination of corporate tax shelter participants. Accounting Review, 84(3), 969-999.

19. Tang, T. (2007). Book-tax differences, a proxy for earnings and tax management. Retrieved from: http://papers.ssrn.com/sol3/papers.cfm?abstract_id=872389.

20. Xie, H. (2011). The mispricing of abnormal accruals. Accounting Review, 76 (3), $357-$ 373.

21. Jackson, M. (2015). Book-tax differences and future earnings changes. Journal of American Taxation Association, 37(2), 49-73. 
22. Kothari, S. P., Leone, A. J., Wasley, C. E. (2005). Performance matched discretionary accruals measures. Journal of Accounting and Economics, 9, 163-197.

23. Haviernikova, K. a kol. (2018). Manažment rizik malých a stredných podnikov $v$ kontexte zapojenia do činnosti klastrov $v$ SR. Trenčín: FSEV. 